\title{
Editorial
}

\section{Corporate branding in a turbulent environment}

Journal of Brand Management (2011) 19, 179-181. doi:10.1057/bm.2011.35

The title of this special issue is: Corporate branding in a turbulent environment. What do we understand by turbulent environment? On the one hand, megatrends, such as consumers assuming multiple societal roles in a rapidly changing environment (99 lives), and craving recognition for their individuality (egonomics), while being confronted with a plethora of goods and services (www faithpopcorn.com/). In this environment, consumers can no longer undertake the extensive evaluation processes required to form their attitude toward a company. The result is a boost in the importance of surrogates such as corporate reputation. On the other hand, companies' communication departments are increasingly challenged by corporate crises. These crises are fueled by savvy consumers using the Internet to influence marketers and the marketplace through pressure and protest. Examining the best-known corporate crises of the past years, we find that minor incidents caused some companies to suffer severely, whereas others survived extremely critical incidents without significant damage. Taking a closer look at those companies that successfully tackled the challenges resulting from a crisis reveals that they had one thing in common: They were highly successful in establishing strong corporate brands to bolster their corporate reputation and engender trust in all the stakeholder groups.

There are many advantages for these successful companies: Investors are more willing to buy and hold shares of such companies, creditors demand lower interest rates, and analysts tend to recommend these firms; politicians are less prone to impose regulatory sanctions on companies they trust; companies with a strong corporate brand are more successful at attracting highly qualified personnel and have higher employee retention rates. And, last but not least, strong corporate brands also affect customers greatly, allowing firms to charge price premiums and increase customer loyalty.

Hence, corporate branding plays a particularly crucial role in building a sustainable bond between the branded company and its stakeholders, most notably its consumers.

When consumers develop a corporate brand image, they build on earlier company-related experiences from multiple sources. They then create a framework for interpreting a corporate image in the present. However, this process is contingent upon environmental factors. In times of economic crisis, consumers particularly prefer brands with a heritage that denotes their credibility, reliability and authenticity. During the past few years, the question of brand heritage, namely how the past and present merge to create a corporate brand image, has gained growing interest in marketing research and managerial practice (for example, Brown et al, 2003; Urde et al, 2007). Wiedmann, Hennigs, Schmidt and Wuestefeld's study ties in with this recent research stream. These scholars investigate the antecedents of brand heritage and its effects on attitudinal components of brand 
strength. The results support the assumption that consumers find a brand's heritage important, resulting in, for example, a lower price sensitivity, as well as a greater willingness to buy and recommend the relevant brand. The study therefore provides deeper insights into the quantifiable effects that originate from the value that heritage brands have in consumers' minds and hearts.

Regardless of whether marketing managers can or cannot build on heritage elements in their brand building activities, the surge in brand advertising and media fragmentation increasingly complicate establishing clear brand associations. In fact, customers are often unintentionally given indistinct and inconsistent brand messages, resulting in brand confusion. When brands confuse consumers, they develop a negative perception of the brand equity, and the brands become dysfunctional. In the second article, Kocyigit and Ringle explore the construct of brand confusion and evaluate its impact on (sustainable) brand satisfaction and proneness to buy private labels. Extending prior research in the field, the authors introduce brand continuity, as well as brand diversity, as new dimensions of brand confusion. These authors show that brand confusion affects sustainable brand satisfaction negatively, leading to a greater proneness to buy private label brands. Brand confusion clearly harms brand equity. Consequently, this study has important implications for marketing managers regarding how to establish unique brand associations.

Establishing unique brand associations requires companies to constantly interact with consumers. Brand communities have become an increasingly popular communication channel that has been shown to be effective for connecting with consumers. Currently, companies increasingly use such communities to facilitate modifications and improvement in customer service, thus improving their brand's image. However, an important issue already discussed in the management information systems literature is the influence of community design on user behaviors in online communities (for example, Ren et al, 2007; Fiedler and Sarstedt, 2010). Tying in with this research, Lee, Lee, Taylor and Lee's study examines brand communities' structural characteristics and shows how they affect online community development and, ultimately, loyalty to the brand. The article makes an important managerial contribution by evaluating how various structural characteristics in an online brand community facilitate emotional attachment and other measures. It thus furthers our understanding of how the structural properties of a brand community can help companies maintain relationships, address crises and build brands. The article also makes a theoretical contribution by demonstrating how network theory can provide a better understanding of how brand communities operate, opening up fruitful areas for future research.

During the last decade, companies have been under increasing scrutiny in terms of social and environmental corporate action (for example, Sarstedt, 2009). Although economic benefits of socially responsible actions (for example, in terms of wordof-mouth, purchasing behavior) have been documented in different studies (for example, Luo and Bhattacharya, 2006; Sen and Bhattacharya, 2001), marketing research still lacks an investigation into the negative influence of ethical brand misconduct. It is this gap in research that Huber, Meyer, Vogel and Vollmann address in this issue's fourth article. These authors offer a holistic point of view of a company's social behavior and analyze the integrative effect of corporate social performance on consumer brand perception. Specifically, their study examines how corporate social performance as a whole, and social responsible behavior and brand misconduct individually, affect brand personality. This study therefore takes a 
further step toward understanding the levers for managing crises that are triggered by unethical brand behavior.

Lastly, DeFanti and Busch pick up the ongoing discussion on the accountability of marketing (for example, Luo and Homburg, 2008; Jacobson and Mizik, 2009; Raithel et al, 2011) by examining a special case: The effect that a corporate name change related to a change in the corporate image has on the firm's stock price. Using an event study approach, this contribution shows that the effect on the firm's stock price is positive. More precisely, a major corporate name change, related to a change in the corporate image, has a positive effect on the stock price, whereas a minor change does not affect it. Finally, corporate name changes that do not alter the brand name have a positive impact on the stock price, whereas those that alter the brand name have a less positive impact. The study refines, expands but also casts doubt on previous research findings in corporate name change, providing important implications for practitioners and researchers alike.

We are grateful to the reviewers who contributed their valuable time and talent to develop this special issue and ensured the quality of the articles with their constructive comments and suggestions. Many of the reviewers were not regular members of the JBM Editorial Review Board and therefore served as ad hoc reviewers. Finally, we would like to thank the Editors-inChief, T. C. Melewar and T. Abimbola for giving us the opportunity to serve the Journal of Brand Management.

\section{REFERENCES}

Brown, S., Kozinets, R.V. and Sherry Jr., J.F. (2003) Teaching old brands new tricks: Retro branding and revival meaning. Journal of Marketing 67(3): 19-33.

Fiedler, M. and Sarstedt, M. (2010) Influence of community design on user behaviors in online communities. ICIS 2010 Proceedings. Paper 112, http://aisel.aisnet.org/icis2010_submissions/112.

Jacobson, R. and Mizik, N. (2009) The financial markets and customer satisfaction: Reexamining possible financial market mispricing of customer satisfaction. Marketing Science 28(5): 836-845.

Luo, X. and Bhattacharya, C.B. (2006) Corporate social responsibility, customer satisfaction, and market value. Journal of Marketing 70(4): 1-18.

Luo, X. and Homburg, C. (2008) Satisfaction, complaint, and the stock value gap. Journal of Marketing 72(4): 29-43.

Raithel, S., Sarstedt, M., Scharf, S. and Schwaiger, M. (2011) On the value relevance of customer satisfaction. Multiple drivers and multiple markets. Journal of the Academy of Marketing Science, forthcoming.

Ren, Y., Kiesler, S. and Kraut, R. (2007) Applying common identity and bond theory to design of online communities. Organization Studies 28(3): 377-408.

Sarstedt, M. (2009) Reputation management in times of crisis. Journal of Brand Management 16(8): 499-503.

Sen, S. and Bhattacharya, C.B. (2001) Does doing good always lead to doing better? Consumer reactions to corporate social responsibility. Journal of Marketing Research 38(5): 225-243.

Urde, M., Greyser, S.A. and Balmer, J.M.T. (2007) Corporate brands with a heritage. Journal of Brand Management 15(1): 4-19.

Manfred Schwaiger and Marko Sarstedt Ludwig-Maximilians-Universität München, Germany 